\title{
Analysis Of Understanding Of Msme Activities In The Preparation Of Financial Statements Based On Sak EMKM And Cooperatives (Case Study Of Msmes In Ratu Agung District, Bengkulu City)
}

\section{Analisis Pemahaman Pelaku Umkm Dalam Penyusunan Laporan Keuangan Berdasarkan Sak EMKM Dan Koperasi (Studi Kasus Umkm Di Kecamatan Ratu Agung Kota Bengkulu)}

\author{
Elisa Fitri 1); Neri Susanti 2); Tito Irwanto 2) \\ 1) Study Program of Accounting Faculty of Econimic, Universitas Dehasen Bengkulu \\ 2) Department of Accounting, Faculty of Economic, Universitas Dehasen Bengkulu \\ Email: ${ }^{1)}$ elisafitri9999@gmail.com; ${ }^{2)}$ nearrysanti@gmail.com; ${ }^{2)}$ titoirwanto@unived.ac.id
}

\section{How to Cite:}

Fitri, E., Susanti, N., Irwanto, T. (2022). Analysis Of Understanding Of Msme Activities In The Preparation Of Financial Statements Based On Sak EMKM And Cooperatives (Case Study Of Msmes In Ratu Agung District, Bengkulu City). Jurnal Ekonomi Manajemen Akuntansi Dan Keuangan, 3(1). DOI: https://doi.org/10.53697/emak.v3i1

\section{ARTICLE HISTORY}

Received [22 Desember 2021]

Revised [30 Desember 2021]

Accepted [10 Januari 2022]

\section{KEYWORDS}

UMKM, Financial Reports, SAK EMKM

This is an open access article under the CC-BY-SA license

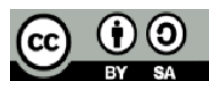

\section{ABSTRAK}

Tujuan dari penelitian ini adalah untuk mengetahui pemahaman pelaku UMKM dalam penyusunan laporan keuangan berdasarkan SAK EMKM dan Koperasi pada UMKM di Kecamatan Ratu Agung Kota Bengkulu. Alat pengumpulan data dilakukan secara dokumentasi dan wawancara tidak terstruktur. Metode analisis yang digunakan adalah analisis deskriptif menurut Miles dan Huberman. Hasil penelitian dan pembahasan mengenai pemahaman pelaku UMKM dalam penyusunan laporan keuangan berdasarkan SAK EMKM dan Koperasi pada UMKM di Kecamatan Ratu Agung Kota Bengkulu khusunya di kelurahan Sawah Lebar kota Bengkulu maka dapat disimpulkan bahwa pelaku UMKM belum terlalu memahami mengenai laporan keuangan yang sesuai dengan SAK EMKM dan Koperasi. Dari 10 UMKM yang diwawancarai, mereka hanya membuat laporan sederhana seperti pencatatan nota penjualan dalam satu hari dan tidak ada membuat rekap pelaporan keuangan selama satu bulan dan satu tahun. Hal ini disebabkan karena masih rendahnya tingkat pemahaman pelaku UMKM terhadap pembuatan laporan keuangan. Para pelaku UMKM belum melakukan pemisahan antara kekayaan pribadi dengan asset usaha karena mereka beranggapan bahwa asset yang mereka miliki masih kecil dan tidak perlu adanya pemisahan dengan asset yang diguakan untuk usaha.

\section{ABSTRACT}

Data collection tools were carried out by means of documentation and unstructured interviews. The analytical method used is descriptif analysis. The results of research and discussion regarding the understanding of MSME actors in preparing financial statements based on SAK EMKM and Cooperatives on MSMEs in Ratu Agung District, Bengkulu City, especially in the Sawah Lebar sub-district, Bengkulu city, it can be concluded that MSME actors do not really understand financial statements in accordance with SAK EMKM and Cooperative. Of the 10 MSMEs interviewed, they only made simple reports such as recording sales notes in one day and did not make a recapitulation of financial reporting for one month and one year. This is

214 | Elisa Fitri, Neri Susanti, Tito Irwanto; Analysis Of Understanding Of... 
due to the low level of understanding of MSME actors towards the preparation of financial reports. MSME actors have not separated personal wealth from business assets because they think that the assets they have are still small and there is no need for separation from assets used for business.

\section{PENDAHULUAN}

Rendahnya pemahaman pelaku UMKM terhadap laporan keuangan disebabkan karena mereka menganggap bahwa usaha mereka masih dalam bentuk skala yang kecil dan mereka tidak memerlukan adanya pemisahan kekayaan antara kekayaan pribadi dan harta usaha. Hal inilah yang menyebabkan pelaku usaha malas untuk membuat laporan keuangan. Para pelaku UMKM hanya mencatat jumlah transaksi penjualan dan pengeluaran saja.

Mayoritas UMKM hanya melakukan pencatatan tentang jumlah dana yang diterima dan biaya yang dikeluarkan, keluar masuknya barang dan jumlah utang atau piutang yang dimiliki. Hal tersebut disebabkan oleh banyak hal yaitu kurangnya pemahaman dari UMKM dalam bidang akuntansi, tidak memiliki tenaga ahli yang dapat melakukan pembukuan sesuai standar, adanya persepsi bahwa pembukuan tidak penting dalam usahanya, persepsi bahwa akuntansi terlalu rumit untuk dilakukan hingga tidak ada pemisahan dana pribadi dan dana yang digunakan dalam proses bisnis. Oleh karena itu, mereka tidak mau untuk menerapkan pembukuan.

Berdasarkan hasil pra penelitian yang dilakukan dengan cara mewawancari beberapa orang pelaku UMKM di kelurahan Sawah Lebar ditemukan bahwa kebanyakan UMKM tidak membuat laporan keuangan lengkap dan hanya mencatat pengeluaran dan pendapatan harian saja secara sederhana. Sementara untuk perhitungan rugi laba juga tidak diketahui karena tidak adanya pencatatan laporan keuangan yang terperinci. Para pelaku UMKM hanya terfokus kepada jumlah penjualan setiap hari. Permasalahan yang dihadapi oleh UMKM ini disebabkan karena kurangnya pemahaman dari para pelaku UMKM dalam memahami laporan keuangan dan juga tidak adanya tenaga kerja atau karyawan yang memahami tentang laporan keuangan. Selain itu juga disebabkan karena pelaku UMKM merasa laporan keuangan tidak mereka butuhkan karena mereka tidak memisahkan antara keuangan usaha dengan keuangan pribadi.

Berdasarkan latar belakang di atas maka penulis mengambil judul penelitian ini dengan judul "Analisis Pemahaman Pelaku UMKM dalam Penyusunan Laporan Keuangan Berdasarkan SAK EMKM dan Koperasi (Studi Kasus UMKM di Kecamatan Ratu Agung Kota Bengkulu)

\section{LANDASAN TEORI}

\section{Pemahaman}

Pemahaman akuntansi sangat diperlukan oleh pengelola usaha dalam menjalankan operasional perusahaan. Motivasi untuk mempelajari tentang Pemahaman akuntansi akan meningkatkan pemahaman manajer atau pemilik dalam menerapkan akuntansi dalam perusahaan (Bedard dan Chi, 2015:99). Pemahaman akuntansi dalam penelitian ini terdiri dari pengetahuan deklaratif dan pengetahuan prosedural.

\section{Laporan Keuangan}

Kasmir (2015:66) berpendapat bahwa: "Laporan keuangan adalah laporan yang menunjukkan kondisi keuangan perusahaan pada saat ini atau dalam suatu periode tertentu." Laporan keuangan merupakan suatu kewajiban dari perusahaan untuk mengetahui posisi keuangan perusahaan dalam satu periode atau satu tahun. 


\section{Standar Akuntansi Keuangan Entitas Mikro Kecil dan Menengah (SAK EMKM) dan Koperasi}

SAK EMKM dan koperasi adalah kepanjangan dari Standar Akuntansi Keuangan Entitas Mikro Kecil Menengah Makro yang dirancang secara khusus sebagai patokan standar akuntasi keuangan pada UMKM. Standar Keuangan ini disusun dan disahkan oleh IAI atau Ikatan Akuntasi Indonesia sebagai sebuah orgnasasi profesi yang menaungi seluruh akuntan di Indonesia dilansir dari iaiglobal.or.id. SAK EMKM ini merupakan salah satu dorongan kepada pengusaha-pengusaha di Indonesia agar dapat berkontribusi secara signifikan dalam pengembangan UMKM yang lebih maju. Mengapa hal ini sangat dibutuhkan untuk usaha terutama UMKM? Karena laporan keuangan merupakan hal yang penting dalam sebuah usaha. Pastinya setiap pengeluaran dan pemasukkan harus jelas dan harus seimbang agar usaha bisa lebih maju lagi.

\section{METODE PENELITIAN}

Penelitian ini adalah penelitian deskriptif, dengan lebih banyak bersifat uraian dari hasil wawancara dan studi dokumentasi. Data yang telah diperoleh akan dianalisis secara kualitatif serta diuraikan dalam bentuk deskriptif. Menurut Sugiyono (2017:103), analisis data adalah "proses mengatur urutan data, mengorganisasikannya ke dalam suatu pola, kategori dan uraian dasar". Definisi tersebut memberikan gambaran tentang betapa pentingnya kedudukan analisis data dilihat dari segi tujuan penelitian. Prinsip pokok penelitian kualitatif adalah menemukan teori dari data

\section{HASIL DAN PEMBAHASAN}

Berdasarkan analisis deskriptif tentang pemahaman pemahaman pelaku UMKM dalam penusunan laporan keuangan berdasrakan SAK EMKM dan koperasi, peneliti dapat mengambil kesimpulan bahwa meskipun ada beberapa poin yang telah dipahami, tetapi secara keseluruhan pemahaman pelaku UMKM di kelurahan Sawah Lebar atas laporan keuangan masih kurang baik. Terbukti bahwa masih ada beberapa responden yang tidak mengetahui siklus akuntansi, tidak mengetahui standar akuntansi untuk UMKM serta rata-rata laporan keuangan yang dipahami hanya laporan laba rugi karena menurutnya yang terpenting dalam usaha adalah dapat mengatahui perkembangan usahanya dan salah satu cara mengukur perkembangan usaha adalah melihat laba usahnya melalui laporan laba rugi.

Menurutya laporan laba rugi berguna untuk kepentingan pajak dan untuk pengajuan kredit atau pembiayaan di Bank sebagai tambahan modal. Masih ada beberapa responden belum mengetahu bahkan belum paham bahwa berdasarkan standar akuntansi yang berlaku mengharuskan entitas menyusun laporan laba rugi, laporan perubahan modal, neraca, laporan mutasi kas dan catatan atas laporan keuangan setiap akhir periode. Peneliti menyimpulkan bahwa pemahaman pelaku UMKM di Sawah Lebar dipengaruhi oleh latar belakang pendidikan karena berdasarkan hasil penelitian responden dengan latar belakang pendidikan SD dan SMP belum memahami tentang siklus akuntansi, standar akuntansi untuk UMKM bahkan konsep penjurnalan transaksi saja belum memahami terbukti dengan hasil hasil wawancara.

Penelitian (Febrianty \& Divianto, 2017) juga menyatakan bahwa pemahaman pelaku usaha terhadap pentingnya laporan keuangan dipengaruhi oleh faktor informasi dan sosialisasi yang diperoleh pelaku usaha, latar belakang pendidikan, lamanya menjalankan usaha dan ukuran usaha yang dijalankan. Faktor terpenting dalam suatu perusahaan salah satunya adalah laporan keuangan karena laporan keuangan menjadi indikator atau petunjuk bagi perusahaan untuk menilai kinerja dari usaha yang dijalankan. 
Maka dari itu perusahaan harus membuat laporan keuangan termasuk di dalamnya sebuah UMKM. Ketika UMKM memiliki laporan keuangan yang sesuai standar akuntansi yang berlaku makan akan berpengaruh terhadap kemampuannya dalam mengakes lembaga keuangan (Yanto et al., 2017). Menurut (Risal et al., 2020) pemahaman yang memadai tentang tujuan usaha sangat dibutuhkan jika perusahaan mau maju. Salah satunya yaitu pemahaman tentang pentingnya akuntansi dan laporan keuangan, karena laporan keuangan adalah alat untuk mengetahui kinerja perusahaan dari segi keuangan. Jika pelaku usaha memiliki pemahaman akuntansi yang baik maka mereka cenderung akan memiliki persepsi bahwa dengan menyusun laporan keuangan itu sangat penting untuk mengetahui perkembangan usahanya.

Pemahaman akuntansi seorang pelaku UMKM berpengaruh terhadap kualitas laporan keuangannya. Ketika seorang pelaku UMKM memiliki pemahaman akuntansi yang baik dengan didukung pengalaman serta latar belakang pendidikan yang sesuai dengan bidangnya maka laporan keuangannya juga akan baik. Pernyataan di atas mendukung hasil penelitian oleh (Risal et al., 2020) yang menyatakan bahwa upaya yang bisa dilakukan pelaku UMKM di Indonesia dalam meningkatkan pemahaman akuntansi adalah dengan cara mengikuti program pendidikan atau pelatihan akuntansi baik formal maupun non formal. Dengan begitu dapat meningkatkan kapabilitas pelaku UMKM dalam menyusun sebuah laporan keuangan usahanya.

Hal tersebut juga didukung hasil penelitian (Kusuma \& Lutfiany, 2019) yang menyatakan bahwa untuk meningkatkan pemaham pelaku UMKM diperlukan semacam program pelatihan atau pendampingan bagi para pelaku UMKM dalam hal mengelola keuangan dengan sistem akuntansi

Berdasarkan standar akuntansi menjelaskan bahwa penyajian wajar dari laporan keuangan yang mematuhi persyaratan dan pengertian laporan keuangan yang lengkap, apabila: penyajian wajar, kepatuhan terhadap standar akuntansi, kelangsungan usaha, frekuensi pelaporan, penyajian yang konsisten, informasi komparatif, materialitas dan agregasi, laporan keuangan lengkap, identifikasi laporan keuangan, yang akan dijelaskan sebagai berikut:

1. Penyajian Wajar

Tujuan pencatatan laporan keuangan bagi suatu usaha yakni untuk menyajikan secara wajar posisi keuangan, kinerja keuangan dan arus kas usaha/perusahaan bisnis tersebut. Penyajian laporan keuangan perusahaan bisnis harus disajikan secara wajar, dalam artian penyajian yang dilakukan bersifat jujur atas pengaruh transaksi, peristiwa dan kondisi lain yang sesuai dengan definisi dan kriteria pengakuan asset, kewajiban, modal, penghasilan dan beban.

Penerapan standar akuntansi dengan pengungkapan tambahan jika diperlukan, menghasilkan laporan keuangan yang wajar atas posisi keuangan, kinerja keuangan, dan arus kas perusahaan. Pengungkapan tambahan diperlukan ketika kepatuhan atas persyaratan tertentu dalam standar keuangan tidak memadai bagi pemakai untuk memahami pengaruh dari transaksi tertentu, peristiwa dan kondisi lain atas posisi keuangan dan kinerja keuangan perusahaan.

Berdasarkan hasil wawancara dengan 10 UMKM yang membuat laporan keuangan dan itupun hanya sekedar pencatatan transaksi saja, sedanngkan UMKM yang lainnya sama sekali tidak pernah melakukan pencatatan atas transaksi penjualan mereka.

Dapat disimpulkan bahwa UMKM di Kelurahan Sawah Lebar masih belum memahami secara keseluruhan mengenai laporan keuangan, sehingga mereka membuat laporan keuangan sesuai kebutuhan usaha mereka tidak mengikuti aturan atau standar akutansi yang ada. Apabila dilihat dari segi kewajaran penyajian laporan keuangan tentu saja hal tersebut masih belum dikatakan wajar karena mereka tidak memperhatikan tentang kriteria pengakuan aset, kewajiban, modal, penghasilan, dan beban. 
2. Kepatuhan terhadap Standar Akuntansi

Perusahaan yang laporan keuangannya mematuhi standar akuntansi harus membuat suatu pernyataan eksplisit dan secara penuh atas kepatuhan tersebut dalam catatan atas laporan keuangan. Berdasarkan hasil wawancara dapat diketahui bahwa ada 10 UMKM yang telah membuat laporan keuangan tetapi mereka belum mematuhi standar akntansi, karena mereka tidak membuat pernyataan secara eksplisit dan secara penuh bahwa mereka telah mematuhi standar akuntansi di dalam catatan atas laporan keuangannya.

Dalam membuat laporan keuangan pun 10 UMKM yang membuat laporan keuangan tersebut tidak mengetahui tentang standar akuntansi dan hanya menghasilkan laporan keuangan yang sesuai kebutuhan usahanya. Jadi meskipun 10 UMKM telah membuat laporan keuangan tersebut, tetapi laporan keuangan tersebut tidak mematuhi standar akuntansi.

3. Kelangsungan Usaha

Pada saat menyusun laporan keuangan, manajemen perusahaan yang menggunakan standar akuntansi membuat penilaian atas kemampuan perusahaan melanjutkan kelangsungan usaha. Perusahaan mempunyai kelangsungan usaha kecuali jika manajemen bermaksud melikuidasi perusahaan tersebut atau menghentikan operasi, atau tidak mempunyai alternatif realistis kecuali melakukan hal-hal tersebut. Dalam membuat penilaian kelangsungan saha, jika manajemen menyadari terdapat ketidakpastian yang material terkait dengan peristiwa atau kondisi yang mengakibatkan keraguan signifikan terhadap kemampuan perusahaan untuk melanjutkan usaha, maka perusahaan harus mengungkapkan ketidakpastian tersebut. Ketika perusahaan tidak menyusun laporan keuangan berdasarkan asumsi kelangsungan usaha, maka fakta tersebut harus diungkapkan, bersama dengan dasar penyusunan laporan keuangan dan alasan mengapa perusahaan tidak dianggap mempunyai kelangsungan usaha. Apabila dilihat dari hasil wawancara dengan 10 UMKM yang membuat laporan keuangan dapat diketahui bahwa pemilik UMKM tersebut hanya berfokus mengelola bisnisnya dalam hal opersional kegiatan usaha.

4. Frekuensi Pelaporan

Perusahaan menyajikan secara lengkap laporan keuangan (termasuk informasi komparatif) minimum satu tahun sekali. Ketika akhir periode pelaporan perusahaan berubah dan pelaporan keuangan tahunan telah disajikan untuk periode yang lebih panjang atau lebih pendek dari satu tahun. Fakta yang ada di lapangan, sembilan UMKM ada yang melakukan pencatatan keuangan secara harian, mingguan, bulanan, bahkan ada yang kadang mencatat terkadang tidak, karena terbatasnya sumber daya manusia yang mereka miliki.

5. Penyajian yang Konsisten

Penyajian dan klasifikasi pos-pos dalam laporan keuangan antar periode harus konsisten kecuali terjadi perubahan yang signifikan atas sifat operasi perusahaan atau perubahan penyajian atau pengklasifikasian bertujuan menghasilkan penyajian lebih baik sesuai kriteria pemilihan dan penerapan kebijakan akuntansi dalam standar keuangan. Jika penyajian at.au pengklasifikasian pos-pos dalam laporan keuangan diubah, maka perusahaan harus mereklasifikasi jumlah komparatif kecuali jika reklasifikasi tidak praktis.

Hasil wawancara dengan 10 UMKM menunjukkan bahwa dalam pencatatan keuangan sebagian besar UMKM belum konsisten dalam mencatat transaksi-transaksi dalam bisnis mereka. Hal tersebut karena mereka tidak terlalu memperhatikan aturan dan tata cara dalam mencatat keuangan, dan setiap UMKM mempunyai cara pencatatan yang berbedabeda, tergantung kreatifitas pemilik UMKM tersebut.

6. Informasi Komparatif 
Informasi harus diungkapkan secara komparatif dengan periode sebelumnya kecuali dinyatakan lain oleh standar keuangan (termasuk informasi dalam laporan keuangan dan catatan atas laporan keuangan). Perusahaan memasukkan informasi komparatif untuk informasi naratif dan deskriptif jika relevan untuk pemahaman laporan keuangan periode berjalan. Hasil wawancara dengan 10 UMKM memperlihatkan bahwa informasi dari pencatatan yang mereka lakukan, informasi yang dihasilkan tidak komparatif karena tidak ada standar dalam pencatatan keuangan yang mereka lakukan.

7. Materialitas

Pos-pos yang material disajikan terpisah dalam laporan keuangan sedangkan yang tidak material digabungkan dengan jumlah yang memiliki sifat atau fungsi yang sejenis. Kelalaian dalam mencantumkan atau kesalahan dalam mencatat suatu pos dianggap material jika, baik secara individual maupun bersama-sama, dapat mempengaruhi pengguna laporan dalam pengambilan keputusan ekonomi. Besaran dan sifat unsur tersebut dapat menjadi faktor penentu.

Berdasarkan hasil wawancara dengan 10 UMKM diketahui bahwa dalam membuat pencatatan keuangan, mereka tidak memperhatikan tingkat materialitas suatu transaksi. Mereka hanya mencatat transaksi tersebut sesuai dengan apa yang terjadi tanpa identifikasi lebih lanjut, tidak ada pemisahan pos-pos yang material dalam pencatatan keuangan yang mereka buat.

8. Laporan Keuangan Lengkap

Berdasarkan standar akuntansi mengenai laporan keuangan lengkap disebutkan bahwa laporan keuangan perusahaan meliputi: neraca, laporan laba/ rugi, laporan perubahan ekuitas yang juga menunjukkan (seluruh perubahan dalam ekuitas, atau perubahan ekuitas selain perubahan yang timbul dari transaksi dengan pemilik dalam kepastiannya sebagai pemilik), laporan arus kas, catatan atas laporan keuangan yang berisi ringkasan kebijakan akuntansi yang signifikan dan informasi penjelasan lainnya.

Hasil wawancara dengan 10 UMKM yang ada di Kelurahan Sawah Lebar diketahui bahwa belum terdapat UMKM yang membuat laporan keuangan, UMKM hanya melakukan pencatata transaksi tanpa membuat laporan keuangan. Hal ini terjadi dikarenakan pelaku UMKM belum memahami mengenai pelaporan keuangan yang sesuai dengan standar akuntansi.

\section{KESIMPULAN DAN SARAN}

\section{Kesimpulan}

Hasil penelitian dan pembahasan mengenai pemahaman pelaku UMKM dalam penyusunan laporan keuangan berdasarkan SAK EMKM dan Koperasi pada UMKM di Kecamatan Ratu Agung Kota Bengkulu khusunya di kelurahan Sawah Lebar kota Bengkulu maka dapat disimpulkan bahwa pelaku UMKM belum terlalu memahami mengenai laporan keuangan yang sesuai dengan SAK EMKM dan Koperasi. Dari 10 UMKM yang diwawancarai, mereka hanya membuat laporan sederhana seperti pencatatan nota penjualan dalam satu hari dan tidak ada membuat rekap pelaporan keuangan selama satu bulan dan satu tahun. Hal ini disebabkan karena masih rendahnya tingkat pemahaman pelaku UMKM terhadap pembuatan laporan keuangan. Para pelaku UMKM belum melakukan pemisahan antara kekayaan pribadi dengan asset usaha karena mereka beranggapan bahwa asset yang mereka miliki masih kecil dan tidak perlu adanya pemisahan dengan asset yang diguakan untuk usaha.

\section{Saran}

1. Untuk pemilik UMKM di kelurahan Sawah Lebar kota Bengkulu untuk mulai memperhatikan pentingnya pembuatan laporan keuangan bagi UMKM karena dengan 
adanya pembuatan laporan keuangan maka UMKM dapat mengetahui besar kecilnya pendapatan yang diterima disetiap bulan dan setiap tahunnya sehingga perusahaan juga dapat mengetahui jumlah keuntungan yang dapat diperoleh setiap bulannya dan dapat dijadikan acuan untuk kedepannya.

2. Untuk Dinas Koperasi dan UMKM kota Bengkulu disarankan untuk memberikan pelatihan dan arahan kepada para UMKM agar UMKM mengerti dan memahami tentang pembuatan laporan keuangna yagn sesuai dengan standar akuntansi yang ada

\section{DAFTAR PUSTAKA}

Fahmi. Irham, 2016. Analisis Kinerja Keuangan. Bandung: ALfabeta

Ikatan Akuntan Indonesia. 2015. Pernyataan Standar Akuntansi Keuangan. Jakarta : Ikatan Akuntan Indonesia

Ikatan Akuntansi Indonesia. (2016). Standar Akuntansi Keuangan Entitas Mikro, Kecil, dan Menengah. Jakarta: Dewan Standar Akuntansi Keuangan Ikatan Akuntansi Indonesia

Kasmir, 2015. Analisis Laporan Keuangan. Jakarta: Rajawali Pers.

Martani, Dewi. 2016. Akuntansi Keuangan Menengah Berbasis PSAK. Jakarta: Salemba Empat

Munawir, S. 2010. Analisis laporan Keuangan Edisi keempat. Cetakan Kelima. Belas. Yogyakarta: Liberty

Mursyidi. 2015. Akuntansi Dasar. Bogor: Ghalia Indonesia

Risal. 2020. Persepsi Pelaku UMKM Dalam Menyusun Laporan Keuangan. Jurnal Riset Akuntansi dan Keuangan Dewantara Vol. 3 No. 1

Santiago, Mohammad David. 2021. Persepsi dan Pemahaman Pelaku Usaha Terhadap Pentingnya Laporan Keuangan pada UMKM. Ekuitas: Jurnal Pendidikan Ekonomi Volume 9, Number 1

Sugiyono, 2014, Metode Penelitian Kombinasi (Mixed Methods), Bandung, Alfabeta

Sulisti. Tanti. 2019. Analisis Tingkat Pemahaman Dan Kesiapan Pelaku Usaha Mikro Kecil Menengah (UMKM) Dalam Implementasi Standar Akuntansi Keuangan Entitas Mikro, Kecil, Dan Menengah (SAK EMKM). Jurnal Ekonomi Universitas Islam Negeri Raden Intan Lampung

Tambunan. Tulus T.H. 2016. Usaha Kecil dan Menengah di Indonesia: Beberapa Isu Penting. Jakarta: Penerbit Salemba Empat.

Undang-Undang Republik Indonesia Nomor 20 Tahun 2008 Tentang Usaha Mikro, Kecil, dan Menengah

Warren, dkk. 2016. Pengantar Akuntansi Adaptasi Indonesia. Jakarta: Salemba Empat. 